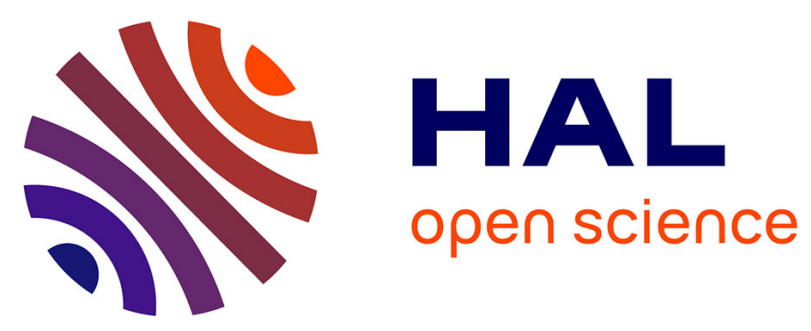

\title{
TEM ANALYSIS OF THE GROWTH OF OXIDE SCALES AT DIFFERENT TEMPERATURES IN FeAl GRADE 3 INTERMETALLIC ALLOY
}

Fernando Pedraza, Jean-Luc Grosseau-Poussard, J.F Dinhut

\section{- To cite this version:}

Fernando Pedraza, Jean-Luc Grosseau-Poussard, J.F Dinhut. TEM ANALYSIS OF THE GROWTH OF OXIDE SCALES AT DIFFERENT TEMPERATURES IN FeAl GRADE 3 INTERMETALLIC ALLOY. Materials at High Temperatures, 2005, 22, pp.545-549. 10.3184/096034005782744263 . hal00512790

\author{
HAL Id: hal-00512790 \\ https://hal.science/hal-00512790
}

Submitted on 1 Sep 2010

HAL is a multi-disciplinary open access archive for the deposit and dissemination of scientific research documents, whether they are published or not. The documents may come from teaching and research institutions in France or abroad, or from public or private research centers.
L'archive ouverte pluridisciplinaire HAL, est destinée au dépôt et à la diffusion de documents scientifiques de niveau recherche, publiés ou non, émanant des établissements d'enseignement et de recherche français ou étrangers, des laboratoires publics ou privés. 


\title{
TEM ANALYSIS OF THE GROWTH OF OXIDE SCALES AT DIFFERENT TEMPERATURES IN FeAI GRADE 3 INTERMETALLIC ALLOY
}

F. Pedraza*, J.L. Grosseau-Poussard, J.F. Dinhut

LEMMA, Université de La Rochelle. 25, rue Enrico Fermi, 17042 La Rochelle cédex 1, FRANCE.

* Corresponding author: Phone: +33 (0)546458297, Fax: +33 (0)546457272, e-mail: fpedraza@univ-lr.fr

\begin{abstract}
Upon the isothermal oxidation of an ODS FeAl Grade 3 intermetallic alloy, a structured oxide scale is developed between 800 and $950^{\circ} \mathrm{C}$. TEM studies have revealed a three-layered structure with a top nanoequiaxed alumina, a central alumina and a bottom Fe-Al spinel. At these temperatures, aluminium outward diffusion does not seem to be suppressed neither by the spinel sub-layer nor by the yttria present in the superalloy. However, the formation of metastable $\theta-\mathrm{Al}_{2} \mathrm{O}_{3}$ seems to be significantly hindered. On the contrary, at $1000^{\circ} \mathrm{C}$, the spinel phase no longer forms but a columnar alumina layer topped up with a nanoequiaxed structure. Yttria seems then to segregate at the scale/alloy interface and to randomly coarsen to produce an Y-Al oxide phase.
\end{abstract}

Keywords: FeAl Grade 3, high temperature, oxide scales, yttria, TEM.

\section{1.- Introduction}

$\mathrm{On} \mathrm{Fe}_{3} \mathrm{Al}$ surfaces, iron oxides have been reported to appear at temperatures lower than $1000^{\circ} \mathrm{C}$ [1] and the extent of metastable and/or protective alumina phases seems to depend on the oxidation temperature and time [2-4]. Conversely, in more aluminiumrich binary and ODS FeAl alloys, the exclusive development of alumina has been reported [5-7], the yttria content affecting the extent of the metastable theta or the stable alpha phases [8]. However, in a more recent study [9] the formation of an iron rich layer underneath alumina was observed to exist in binary FeAl. In this work, it is intended to study the evolution of oxide scales at increasing temperatures and to examine whether the formation of such iron oxides also occurs in the $\mathrm{Y}_{2} \mathrm{O}_{3}$ alloyed counterpart, i.e. ODS FeAl Grade 3 alloy.

\section{2.- Experimental Procedure}


The samples of ODS FeA140 Grade $3\left(0.1 \mathrm{wt} \% \mathrm{Zr}, 1 \mathrm{wt} \% \mathrm{Y}_{2} \mathrm{O}_{3}\right)$ [CEA/CEREM, Grenoble, France] consisted of discs (15 mm diameter x $1 \mathrm{~mm}$ thickness) polished to final roughness of $0.01 \mu \mathrm{m}$ that were thoroughly rinsed in $96 \%$ ethanol prior to oxidation. The isothermal tests were conducted in a $\pm 10^{-6} \mathrm{~g}$ accurate thermobalance (Setaram TGA-92). The heating and cooling rate constants were set at $50^{\circ} \mathrm{C} \cdot \mathrm{min}^{-1}$. An inert flow of Ar gas was introduced in the oxidation chamber to avoid any oxidation until the different temperatures $\left(800\right.$ to $\left.1000^{\circ} \mathrm{C}\right)$ were reached, at which a $0.61 . \mathrm{min}^{-1}$ flow of synthetic air was let in for $24 \mathrm{~h}$.

After oxidation, the samples were characterised by conventional $\theta-2 \theta$ configuration $X-$ ray diffraction (XRD) (Bruker 5005-D) and scanning electron microscopy (SEM) coupled to energy-dispersive spectrometry (EDS) in a JEOL JSM-4510 LV.

TEM cross section studies were also carried out to study more accurately the evolution of the oxide scales with the increasing temperature in a JEOL-JEM 2010 at $200 \mathrm{kV}$. For such purpose, thinning of back-to-back glued specimens included cutting of thin discs with a diamond saw followed by manual polishing to obtain about $50 \mu \mathrm{m}$ thick foils. These foils were then pierced with a Gatan precision ion polishing system (PIPS ${ }^{\mathrm{TM}}$ ) model 691 alternating the ion beams with the two guns and varying the impinging angles.

\section{3.- Results and discussion}

The TEM cross section of the raw FeAl Grade 3 material [Figure 1(a)] shows elongated grains of about $1 \times 0.5 \mu \mathrm{m}$ in agreement with the previous observations of Montealegre et al. [7] as a result of the extrusion process. The selected area diffraction patterns clearly reveal the typical superstructure B2 of FeAl [Figure 1 (b)]. Within the grains and at the grain boundaries, a random distribution of $\mathrm{Y}_{2} \mathrm{O}_{3}$ appears characterised by the white dots in the dark field mode of Figure 1(a). Occasionally, $\mathrm{Zr}$ is found to segregate within the grains of the raw materials.

Figure 2 shows the oxidation behaviour of this material at different temperatures for 24 h. The mass gain per unit area increases with increasing temperature from 800 to $900^{\circ} \mathrm{C}$, as expected. However, at $950^{\circ} \mathrm{C}$ quite a remarkable increase is observed to occur, which 
might be associated to the development of a different oxide scale. At $1000^{\circ} \mathrm{C}$, a sharp decrease of the mass gain per unit area takes place. This curve shows a trend rather different than the ones observed at lower temperatures suggesting a different oxide scale growth mechanism.

If a parabolic behaviour is assumed to occur at all temperatures, different constants can be calculated depending on the oxidation time (Table 1). A transition period between the first and second parabolic oxidation stage always occurs except for $800^{\circ} \mathrm{C}$. This time interval appears at shorter oxidation times with the increasing temperature. The transition seems to be somewhat longer for the $950^{\circ} \mathrm{C}$, indicating the formation of more than one oxide species or that the $\theta-\mathrm{Al}_{2} \mathrm{O}_{3}$ into $\alpha-\mathrm{Al}_{2} \mathrm{O}_{3}$ is not completed [9]. At $1000^{\circ} \mathrm{C}$, the oxidation curve versus $\mathrm{t}^{1 / 2}$ has been forced to follow a parabolic law and clearly shows much slower oxidation rates at any interval than at $950^{\circ} \mathrm{C}$. However, the transition period is of about $6 \mathrm{~h}$ because of the deviation from the parabolic behaviour typical of a simple solid state diffusion process. Overall, the oxidation behaviour is slower than that reported by Mignone et al. [5] for the ODS FeAl with $0.5 \mathrm{wt} \% \mathrm{Y}_{2} \mathrm{O}_{3}$ and MA 956 (FeCrAlY alloy).

The X-ray diffraction patterns (Figure 3) of the oxidised surfaces show the presence of some reflections corresponding to the spinel phase $\mathrm{FeAl}_{2} \mathrm{O}_{4}$ (JCPDS-34-192), with some of the peaks relatively overlapping with those the parent material. The $\alpha-\mathrm{Al}_{2} \mathrm{O}_{3}$ phase is present at all the oxidation temperatures but not the $\theta$-phase, which is clearly identified at $950^{\circ} \mathrm{C}$ with a major peak.

The observation of the SEM surfaces indicates that the oxide scales seem to become denser with the increasing temperature because of the disappearance of the pores of this powder metallurgy manufactured substrate. Moreover, the scales seem to adhere well to the substrate. In the rare spalled areas, polygonal voids appear, suggesting main outward cation diffusion (Figure 4). On their isothermal oxidation studies at $1100^{\circ} \mathrm{C}$ of the same ODS FeAl Grade 3 substrate, Montealegre et al. [8] related the spallation of the pure alumina scales to the differences in the thermal expansion coefficients of alumina and the metallic substrate but no void formation was reported to occur, probably due to the faster ionic diffusion associated at higher temperatures. This feature already suggests 
that the role of yttrium (scale adherence enhancement [10], suppression of major outward aluminium diffusion [11,12] and prevention of void formation [13]) seems to be negligible at relatively low temperatures. However, Czyrska-Filemonowicz et al. $[14,15]$ showed that an excessive amount of yttria could lead to a large number of cavities at the oxide grain boundaries as a result of microcrack formation at the grain boundaries of various ODS superalloys (PM2000, PM2002 and MA956) after oxidation at 1100 and $1200^{\circ} \mathrm{C}$ for times of $5-1000 \mathrm{~h}$.

In Figure 4 the typical needle-like morphology of the $\theta-\mathrm{Al}_{2} \mathrm{O}_{3}$ phase is also observed [8]. From the surface SEM/EDS analyses different $\mathrm{Al} / \mathrm{Fe}$ ratios are recorded depending on the oxidation temperature. Indeed, at temperatures lower than $1000^{\circ} \mathrm{C}$ the $\mathrm{Al} / \mathrm{Fe}$ may suggest the formation of a $\mathrm{FeAl}_{2} \mathrm{O}_{4}$ oxide whereas only aluminium oxides should occur at $1000^{\circ} \mathrm{C}$.

The TEM cross-section studies of the scales grown at 850,900 and $950^{\circ} \mathrm{C}$ reveal a double structure as the one shown in Figure 5 (a). Between both layers, a flat interface develops, contrary to the wavy internal substrate/scale interface, which seems to result from internal oxidation of the substrate. At higher magnification, it was found that the Fe/Al spinel oxide was mainly located at the inner layer whereas alumina constituted the external one. This spinel oxide may develop during the initial stages (faster $k_{p}$ values) together with $\alpha-\mathrm{Al}_{2} \mathrm{O}_{3}$ at the outermost surface [16] and may be the result of the reaction between $\mathrm{Al}_{2} \mathrm{O}_{3}$ and $\mathrm{Fe}_{2} \mathrm{O}_{3}$, as concluded from in situ high temperature XRD studies [17].

The 3-nm point TEM/EDS analyses across these layers suggest major outward aluminium flow through the inner scale. At higher magnification a third top scale is found, which has an equiaxed morphology of nanometre scale [Figure 5 (b)]. This suggests that after the first oxidation stage and the transition period faster aluminium outward diffusion may occur giving rise to the development of the nanometre sized alumina thin scale on top of the $\mathrm{FeAl}_{2} \mathrm{O}_{4}$ layer. Equiaxed grained morphology has also been observed to occur in alumina scales developed on ODS FeCrAl alloys by countercurrent diffusion of oxygen and aluminium, with molecular oxygen transport occurring through defects developed in the scale [18]. Nevertheless, oxygen inward 
diffusion is not fully suppressed as indicated by the Al-rich oxide intrusions of the substrate material [Figure 5 (a)]. The development of such scale configuration is confirmed in Figure 5 (c), in which the electron diffraction pattern of the overall scale is shown clearly depicting the presence of both the $\mathrm{FeAl}_{2} \mathrm{O}_{4}$ spinel and $\alpha-\mathrm{Al}_{2} \mathrm{O}_{3}$ oxides, as summarised in Table 2.

At $1000^{\circ} \mathrm{C}$, the oxide scales show a complete different morphology. At this temperature, columnar grains of $\alpha-\mathrm{Al}_{2} \mathrm{O}_{3}$ clearly develop from the substrate/scale interface as shown in Figure 6 (a). A closer examination of this image reveals that the grains are topped up with the previously shown equiaxed grains of nanometre scale, which reflects the relatively high rates of nucleation and growth at the beginning of oxidation [19]. However, preferential inward oxygen diffusion seems to occur along the significant amount of grain boundaries oxidising the substrate so that columnar grains develop [13,18]. The TEM/EDS composition profiles [Figure 6 (b)] clearly show aluminium as the major metallic constituent of the oxide layer. Yttrium seems to preferentially segregate at the oxide/substrate interface and all the attempts to find this element at any other location of the oxide scale (including grain boundaries) were generally unsuccessful even in the dark field mode. Therefore, the low concentration of these precipitates at the scale/substrate interface should not significantly influence the oxidation behaviour of the ODS FeAl [13]. U1-Hamid [20] also showed by TEM that the alumina scales developed on $\mathrm{Ni}-10 \mathrm{Cr}-\mathrm{Al}$ were not affected by the presence of yttrium in the early stages of oxidation, which agrees well with our observations.

\section{5.- Summary}

The isothermal oxidation rate of ODS FeAl intermetallic alloy increases with increasing temperature up to $950^{\circ} \mathrm{C}$ during the tests carried out for $24 \mathrm{~h}$ under synthetic air. The scales show a three-layered structure in which a $\mathrm{FeAl}_{2} \mathrm{O}_{4}$ spinel phase composes the bottom layer, the centre and top layers being of alumina. Once the spinel layer forms at the shortest oxidation stages, subsequent aluminium diffusing outwardly occurs, which giving rise to an equiaxed alumina scale by reaction with inwardly diffusing oxygen.

At $1000^{\circ} \mathrm{C}$, the oxidation regime differs and only two oxide layers are found to develop. The top alumina layer always shows an equiaxed structure of nanometre scale 
again arising from rapid inward and outward cation diffusion. However, the spinel layer is no longer observable and a columnar alumina layer develops from the substrate towards the gas/scale interface, probably due to a major oxygen inward diffusion.

At any temperature, aluminium outward diffusion does not seem to be suppressed at these temperatures by the low density of yttria dispersion segregated at the scale/substrate interface. However, the metastable $\theta-\mathrm{Al}_{2} \mathrm{O}_{3}$ oxide formation is significantly hindered.

\section{4.- References}

1. Pint, B.A., Leibowitz, J., de Van, J.H., The effect of an oxide dispersion on the critical Al content in Fe-Al alloys, Oxid. Met. 51 (1/2), 181-197 (1999).

2. Babu, N., Balasubramaniam, R., Gosh, A. High-temperature oxidation of $\mathrm{Fe}_{3} \mathrm{Al}-$ based iron aluminides in oxygen, Corr. Sci. 43 (12), 2239-2254 (2001).

3. Pint, B.A., Regina, J.R., Prussner, K., Chitwood, L.D., Alexander, K.B, Tortorelli, P.F. Effect of environment on the oxidation of ingot-processed iron aluminides, Intermetallics 9 (8), 735-739 (2001).

4. Kim, I., Cho, W.D., Kim, H.J. High-temperature oxidation of $\mathrm{Fe}_{3} \mathrm{Al}$ containing yttrium, J. Mater. Sci. 35 (18), 4695-4703 (2000).

5. Mignone, A., Frangini, S., La Barbera, A., Tassa, O. High temperature corrosion of B2 iron aluminides Corr. Sci. 40 (8) 1331-1347 (1998).

6. Xu, C.H., Gao, W., He, Y.D., High temperature oxidation behaviour of FeAl intermetallics - oxide scales formed in ambient atmosphere, Scripta Mater. 42 (10) 975-980 (2000).

7. Montealegre, M.A., González-Carrasco, J.L., Morris-Muñoz, M.A., Chao, J., Morris, D.G. The high temperature oxidation behaviour of an ODS FeAl alloy, Intermetallics 8 (4) 439- 446 (2000).

8. Montealegre, M.A., González-Carrasco, J.L. Influence of the yttria content on the oxidation behaviour of the intermetallic Fe40Al Alloy, Intermetallics 11 (2) 169175 (2003).

9. Dang Ngoc Chan, C., Huvier, C., Dinhut, JF. High temperature corrosion of some B2 iron aluminides, Intermetallics 9 (9) 817-826 (2001).

10. García-Alonso, M.C., González-Carrasco, J.L., Pérez, P., Haannappel, V.A.C., Escudero, M.L., Chao, J., Stroosnijder, M.F. A surface modified ODS superalloy by 
thermal oxidation for potential implant applications J. Mater. Sci. Mat. Med. 12 (7) 589-596 (2001).

11. López, M.F., Gutiérrez, A., García-Alonso, M.C., Escudero, M.L. Surface analysis of a heat treated, Al-containing, iron-based superalloy, J. Mater. Res. 13 (12) 34113416 (1998).

12. Weinbruch, S., Anastassiadis, A., Ortner, H.M., Martinz, H.P., Wilhartitz, P. On the mechanism of high-temperature oxidation of ODS superalloys: significance of yttrium depletion within the oxide scales, Oxid. Met. 51 (1/2) 111-128 (1999).

13. Mennicke, C., Schumann, E., Rühle, M., Hussey, R.J., Sproule, G.I., Graham, M.J., The effect of Yttrium on the growth process and microstructure of $\alpha-\mathrm{Al}_{2} \mathrm{O}_{3}$ on FeCrAl Oxid. Met. 49 (5/6) 455-466 (1998).

14. Czyrska-Filemonowicz, A., Clemens, D., Quadakkers, W.J. The effect of high temperature exposure on the structure and oxidation behaviour of mechanically alloyed ferritic ODS alloys J. Mater. Proc. Technol. 53 (1-2) 93-100 (1995).

15. Czyrska-Filemonowicz, A., Szot, K., Wasilkowska, A., Gil, A., Quadakkers, W.J. Microscopy (AFM, TEM, SEM) studies of oxide scale formation on FeCrAl based ODS alloys, Solid State Ionics 117 (1-2) 13-20 (1999).

16. Pérez, F.J., Pedraza, F., Hierro, M.P., Balmain, J., Bonnet, G. Comparison of the high-temperature oxidation of uncoated and CVD-FBR aluminized AISI-304 stainless steel, Oxid. Met. 58 (5/6) 563-588 (2002).

17. Fujimura, T., Tanaka, S.I. In-situ high temperature X-ray diffraction study of $\mathrm{Fe} / \mathrm{Al}_{2} \mathrm{O}_{3}$ interface reactions J. Mater. Sci. 34 (3) 425-429 (1999).

18. Quadakkers, W.J., Naumenko, D., Singheiser, L., Penkalla, H.J., Tyagi, A.K., Czyrska-Filemonowicz, A. Batch to batch variations in the oxidation behaviour of alumina forming Fe-based alloys Mat. Corr. 51 (5) 350-357 (2000).

19. Ul-Hamid, A. TEM study of the effect of $\mathrm{Y}$ on the scale microstructures of $\mathrm{Cr}_{2} \mathrm{O}_{3}$ and $\mathrm{Al}_{2} \mathrm{O}_{3}$-forming alloys, Oxid. Met. 58 (1/2) 23-40 (2002).

20. U1-Hamid, A. TEM study of scale microstructures formed on $\mathrm{Ni}-10 \mathrm{Cr}$ and $\mathrm{Ni}-$ 10Cr-5Al alloys with and without Y addition, Oxid. Met. 58 (1/2) 41-56 (2002) 
Table 1.- Parabolic rate constants, $\mathrm{k}_{\mathrm{p}}$, and time intervals of FeAl Grade 3 as a function of the oxidation temperature and up to $24 \mathrm{~h}$.

\begin{tabular}{|c|c|c|c|}
\cline { 2 - 4 } \multicolumn{1}{c|}{} & \multicolumn{3}{|c|}{$\mathrm{k}_{\mathrm{p}}\left(\mathrm{mg}^{2} \cdot \mathrm{cm}^{-4} \cdot \mathrm{s}^{-1}\right) \times 10^{7}$} \\
\cline { 2 - 4 } & First stage & Transition & Second stage \\
\hline \multirow{2}{*}{$800^{\circ} \mathrm{C}$} & $0-8 \mathrm{~h}$ & none & 0.51 \\
\hline $850^{\circ} \mathrm{C}$ & $0-6 \mathrm{~h}$ & $6-8 \mathrm{~h}$ & $8-24 \mathrm{~h}$ \\
& 0.79 & & 0.56 \\
\hline $900^{\circ} \mathrm{C}$ & $0-4 \mathrm{~h}$ & $4-6 \mathrm{~h}$ & $6-24 \mathrm{~h}$ \\
& 1.20 & & 0.58 \\
\hline $950^{\circ} \mathrm{C}$ & $0-2 \mathrm{~h}$ & $2-6 \mathrm{~h}$ & $6-24 \mathrm{~h}$ \\
& 2.10 & & 1.60 \\
\hline $1000^{\circ} \mathrm{C}$ & $0-6 \mathrm{~h}$ & $6-12 \mathrm{~h}$ & $12-24 \mathrm{~h}$ \\
& 0.40 & & 0.85 \\
\hline
\end{tabular}


Table 2.- Experimental d-spacings obtained from SADPs at the different oxide layers composing the scales developed in ODS FeAl oxidised between 850 and $950^{\circ} \mathrm{C}$ and their correspondence to the planes of the identified compounds.

\begin{tabular}{ccc}
\hline d-spacing, $\AA$ & $\begin{array}{c}\mathrm{FeAl}_{2} \mathrm{O}_{4} \\
(\mathrm{JCPDS} 34-192)\end{array}$ & $\begin{array}{c}\alpha-\mathrm{Al}_{2} \mathrm{O}_{3} \\
(\mathrm{JCPDS} 83-2081)\end{array}$ \\
\hline 4.65 & 111 & - \\
2.84 & 220 & - \\
2.46 & 311 & - \\
2.05 & 400 & 113 \\
1.67 & 422 & - \\
1.55 & 511 & - \\
1.44 & 440 & - \\
1.16 & 444 & - \\
\hline
\end{tabular}




\section{$\underline{\text { List of Figure Captions }}$}

Figure 1.- (a) TEM dark field image of the as-received FeAl Grade 3 intermetallic alloy showing homogeneous grain size and random distribution of some $\mathrm{Y}_{2} \mathrm{O}_{3}$ particles and

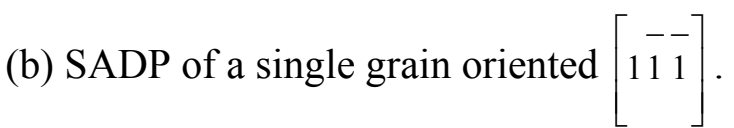

Figure 2.- Mass gain per unit area of the ODS FeAl Grade 3 isothermally oxidised at different temperatures for $24 \mathrm{~h}$ in synthetic air.

Figure 3.- X-ray diffractograms of the non oxidised ODS FeAl Grade 3 (R.T. = room temperature) and after its isothermal oxidation at different temperatures for $24 \mathrm{~h}$ in synthetic air.

Figure 4.- SEM detail of a spalled zone of the oxide scale developed on FeAl Grade 3 after oxidation at $900^{\circ} \mathrm{C}$ for $24 \mathrm{~h}$ under synthetic air showing different oxide features and voids.

Figure 5.- TEM cross-section of the specimens oxidised at $850^{\circ} \mathrm{C}$ for $24 \mathrm{~h}$. (a) General view showing the scale divided into two main layers and internal oxidation of the substrate (b) Detail of the top equiaxed morphology at the gas/scale (c) SADP of the overall scale.

Figure 6.- (a) TEM Columnar morphology of the scale developed on ODS FeAl Grade alloy isothermally oxidised at $1000^{\circ} \mathrm{C}$ for $24 \mathrm{~h}$ under synthetic air. Arrow marks indicate the top equiaxed nanograined alumina and the corresponding EDS ( $3 \mathrm{~nm}$ spot size ) composition profiles. 

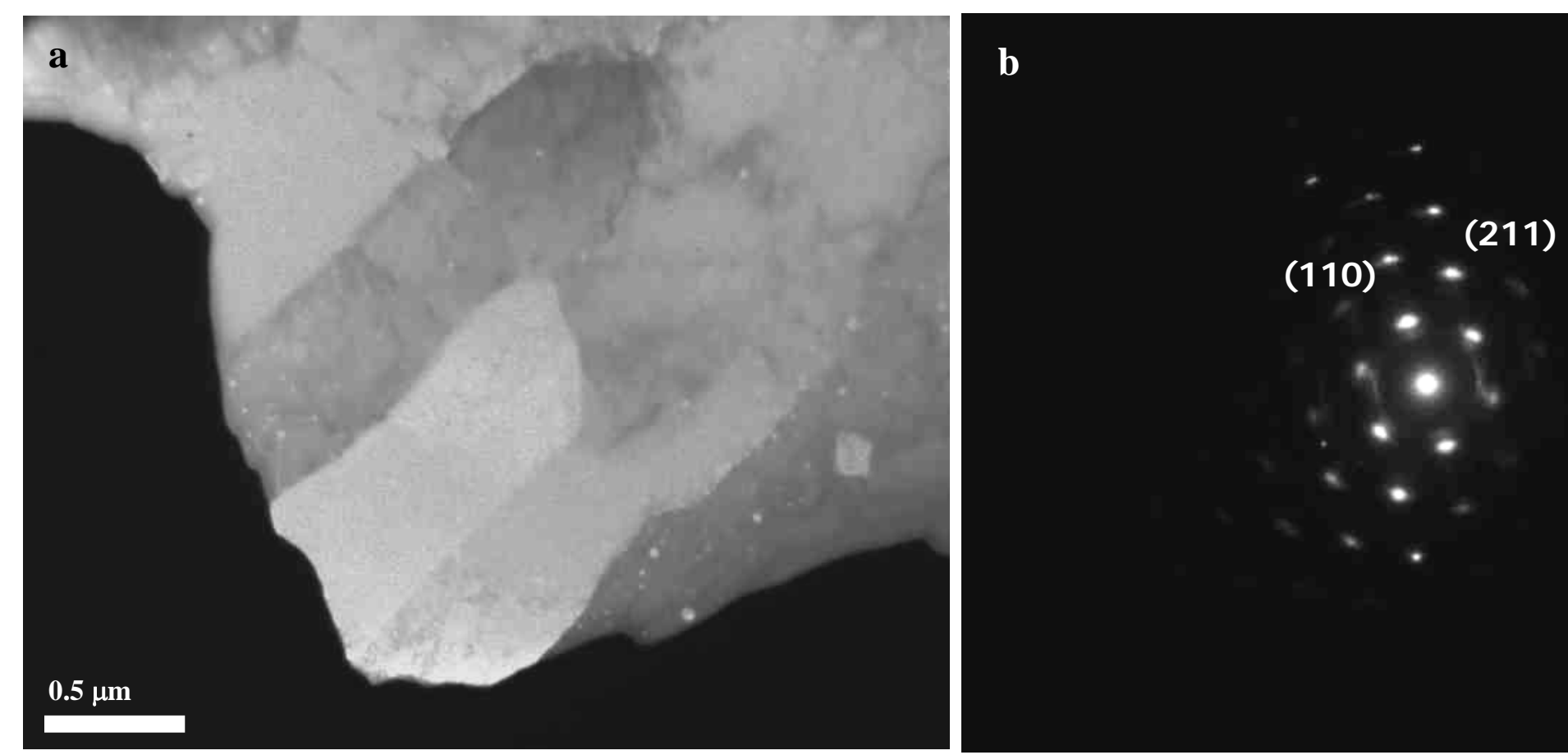

Figure 1.- (a) TEM dark field image of the as-received FeAl Grade 3 intermetallic alloy showing homogeneous grain size and random distribution of some $\mathrm{Y}_{2} \mathrm{O}_{3}$ particles and (b) SADP of of a single grain oriented $\left[\begin{array}{cc}-- \\ 1 & 1\end{array}\right]$. 


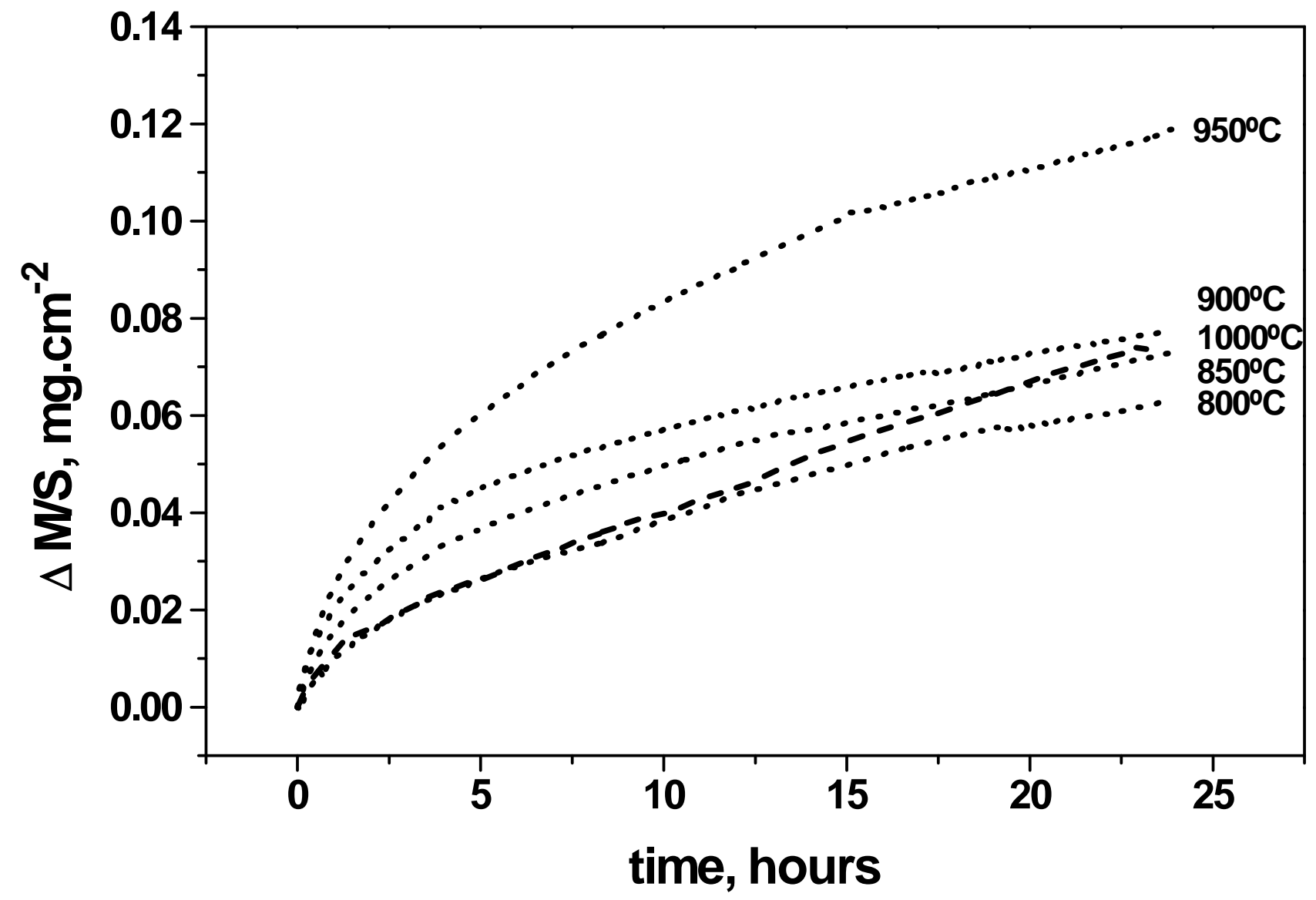

Figure 2.- Mass gain per surface unit of the ODS FeAl Grade 3 isothermally oxidised at different temperatures for $24 \mathrm{~h}$ in synthetic air. 


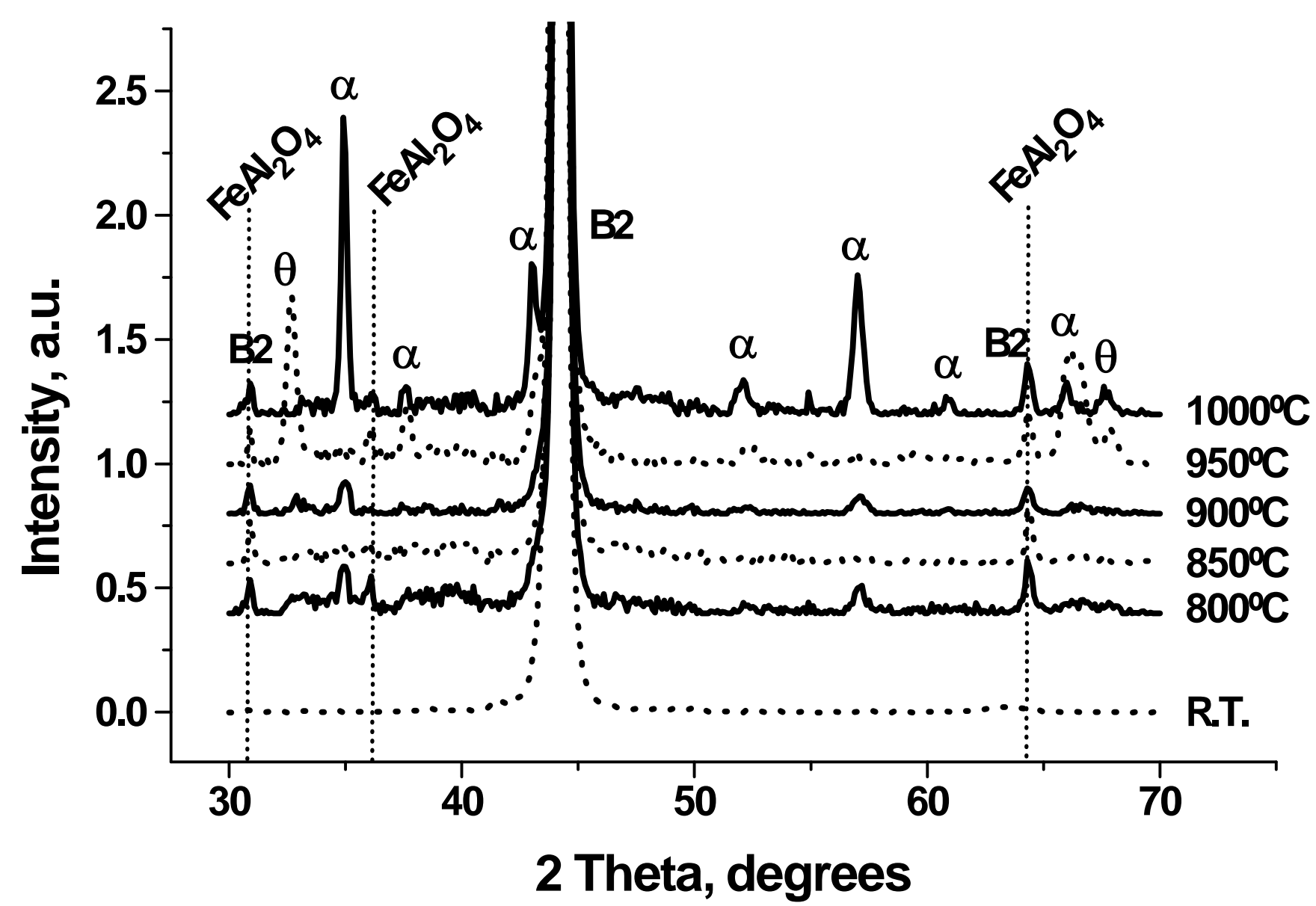

Figure 3.- X-ray diffractograms of the non oxidised ODS FeAl Grade 3 (R.T. = room temperature) and after its isothermal oxidation at different temperatures for $24 \mathrm{~h}$ in synthetic air. 


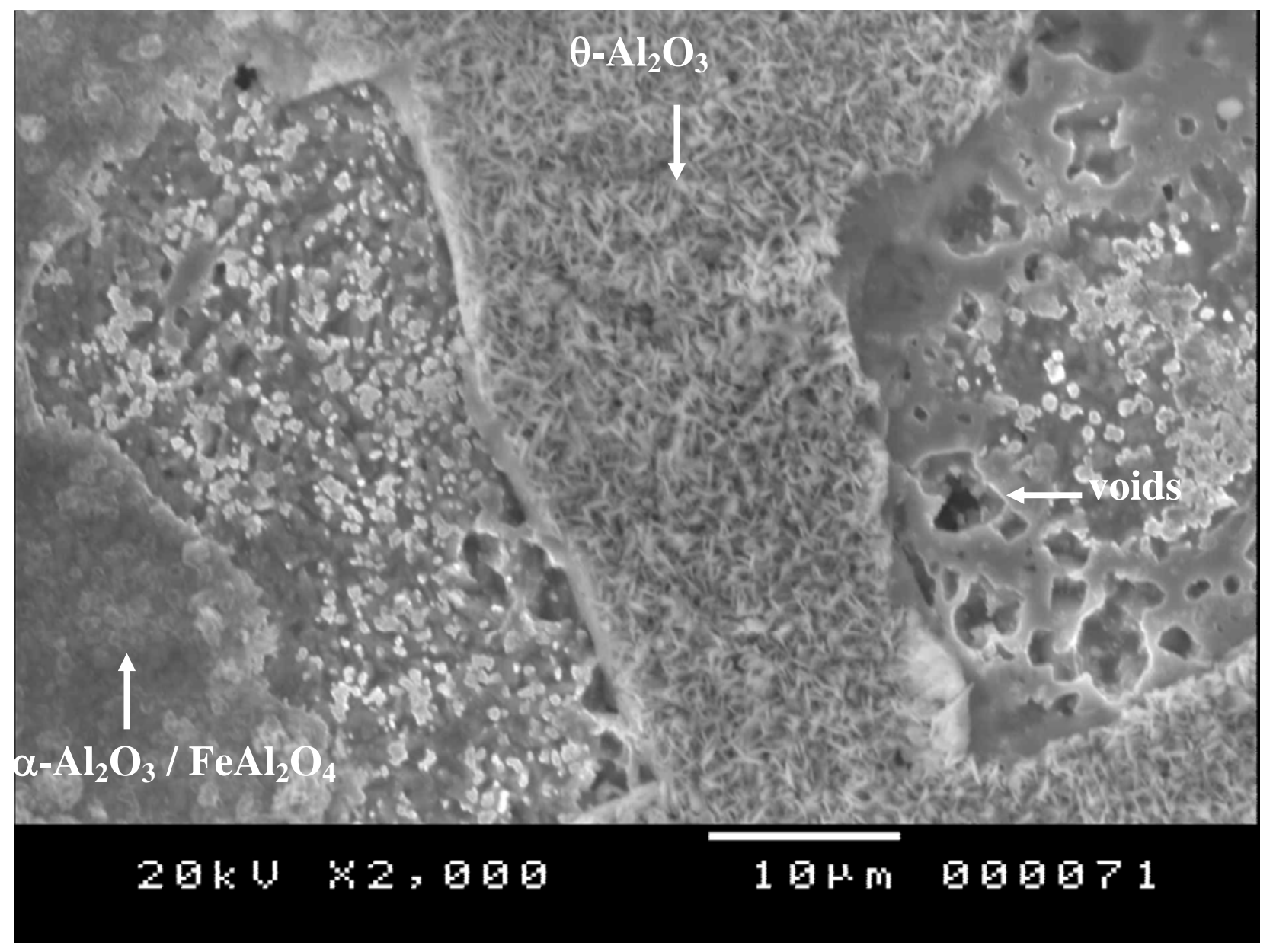

Figure 4.- SEM detail of a spalled zone of the oxide scale developed on FeAl Grade 3 after oxidation at $900^{\circ} \mathrm{C}$ for $24 \mathrm{~h}$ under synthetic air showing different oxide features and voids. 

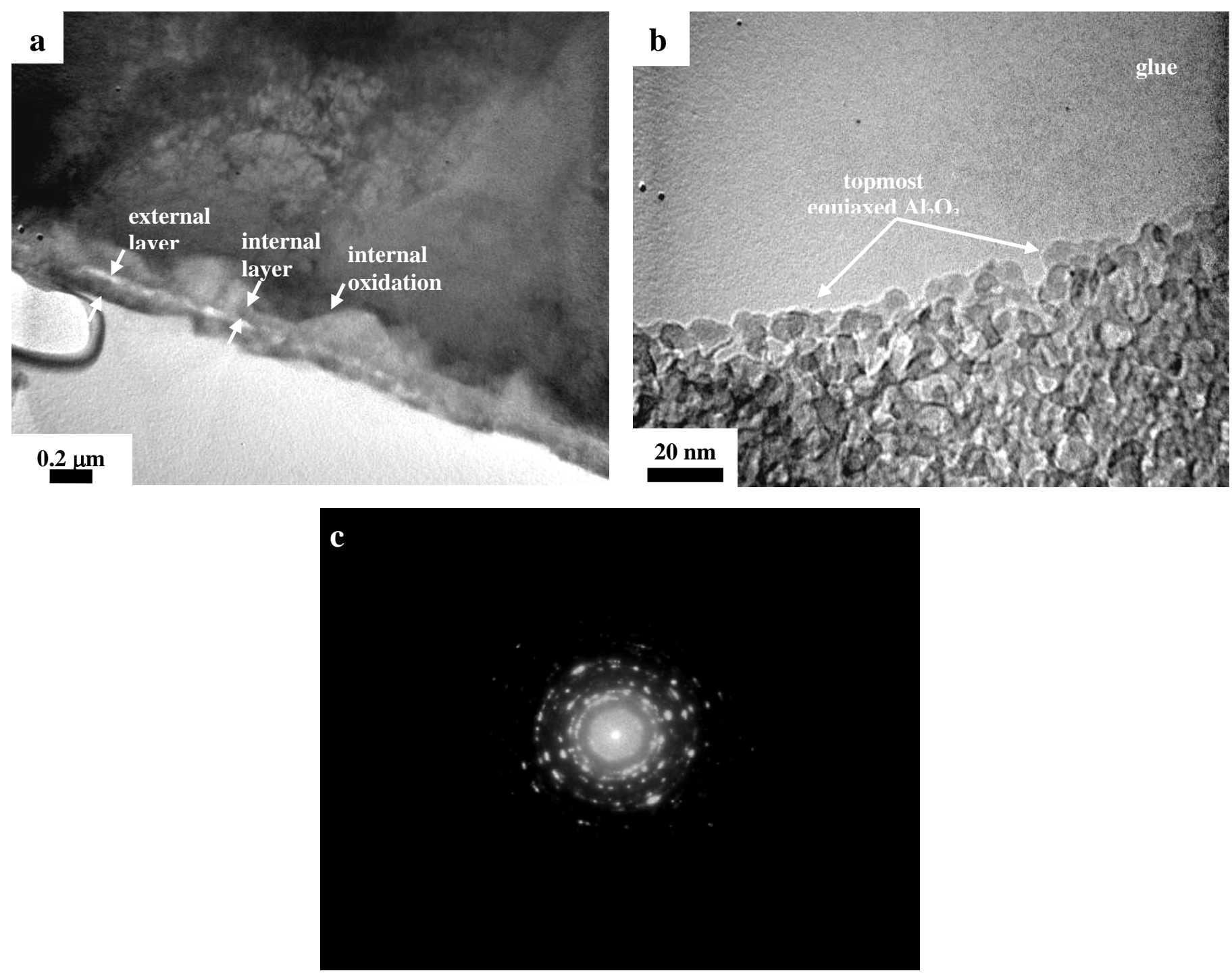

Figure 5.- TEM cross-section of the specimens oxidised at $850^{\circ} \mathrm{C}$ for $24 \mathrm{~h}$. (a) General view showing the scale divided into two main layers and internal oxidation of the substrate (b) Detail of the top equiaxed morphology at the gas/scale (c) SADP of the overall scale. 

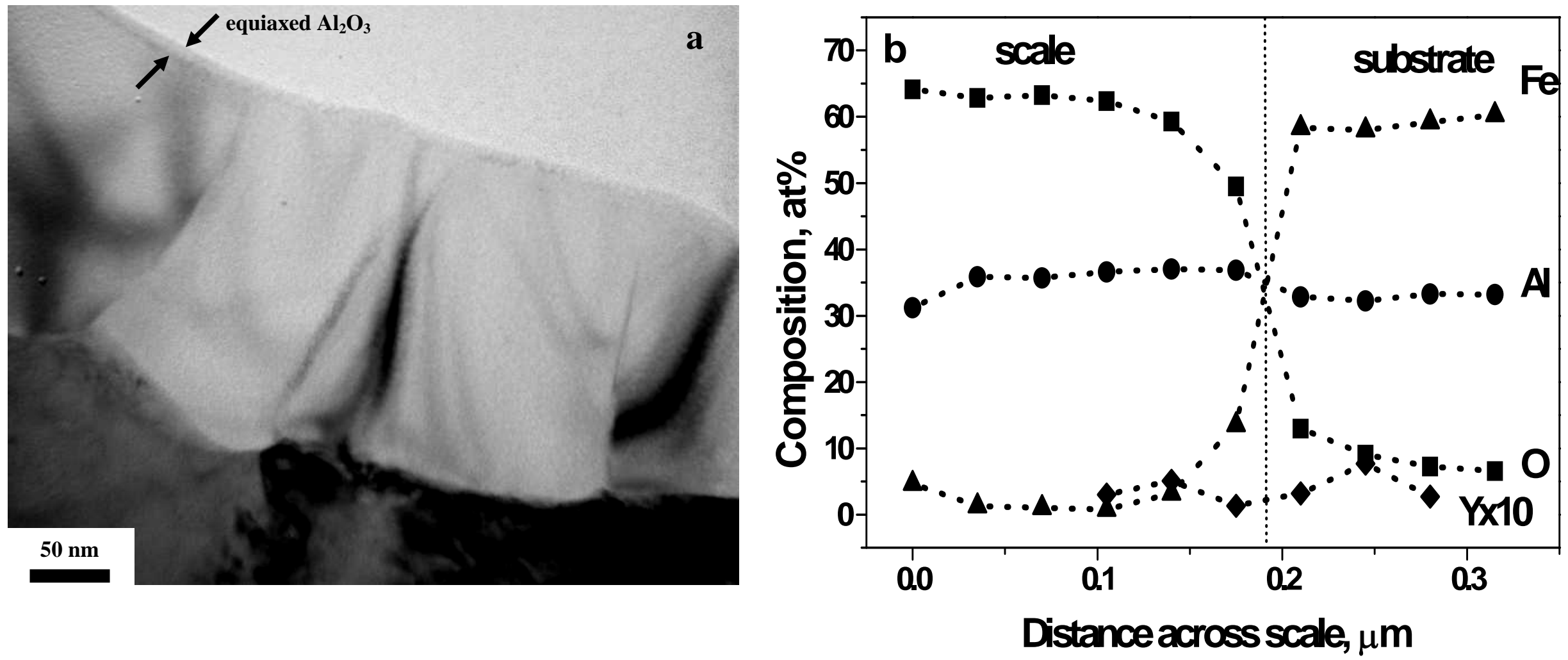

Figure 6.- (a) TEM Columnar morphology of the scale developed on ODS FeAl Grade alloy isothermally oxidised at $1000^{\circ} \mathrm{C}$ for $24 \mathrm{~h}$ under synthetic air. Arrow marks indicate the top equiaxed nanograined alumina and the corresponding EDS (3 $\mathrm{nm}$ spot size ) composition profiles. 